\title{
The Effect of Multi-walled Carbon Nanotubes on Pennycress (Thlaspi arvense L.) Plant
}

\author{
Noha S. Khalifa \\ Genetic Unit, Botany Department, Faculty of Science, Ain Shams University, Cairo, \\ Egypt.
}

\begin{abstract}
$\mathbf{M}$ ULTI walled carbon nanotubes (MWCNT) are gaining more attention to be used in industry and agriculture. The effect of this new nanomaterial should be investigated in order to gain more understanding about its effect on living organisms. In this study, pennycress plant was used as a model to determine the effect of MWCNT on the whole plant as well as its free genomic DNA. Germinated seedlings of pennycress plants were grown on MS agar media supplemented with 25,100 and $200 \mu \mathrm{g} / \mu \mathrm{l}$ MWCNT for 6 days. The root elongation assay indicated that $25 \mu \mathrm{g} / \mu \mathrm{l}$ of MWCNT enhanced the plant growth while the growth rate was reduced at higher concentrations. The gel shift binding assay indicated that MWCNT exhibited the ability to bind the genomic DNA at higher concentrations of 100 and $200 \mu \mathrm{g} / \mu \mathrm{l}$ while no binding was observed at lower concentration of $25 \mu \mathrm{g} / \mu \mathrm{l}$. This study also showed that the plant pigment was highly reduced at higher concentrations as will be further discussed.
\end{abstract}

Keywords: Pennycress, Multiwalled carbon nanotube (MWCNT), DNA, Photosynthetic pigments.

\section{Introduction}

Recent years witnessed a significant increase in the interest of engineered nanomaterials (ENM) and their applications in many fields. Due to their unique physicochemical properties such as high surface area and high reactivity, nanoparticles (NPs) could presumably serve as the magic bullets in many aspects. They can be used as herbicides, nano-fertilizers (Mehrazar et al., 2015), drug delivery systems (De Jong \& Borm, 2008) or gene transfer tools (Kovtun et al., 2013). In addition, NPs can act as signaling molecules that would target specific cellular organelles to release their content or control their gene expression (Siddiqi \& Husen, 2016).

Advances in nanotechnology have led to largescale production of nanoparticles that in turn increases the chances of environmental exposure. Although humans, workers and users in particular, are primarily at risk of being exposed to NPs, the effect on plants cannot be ignored for many reasons. Plants are the main components of food chain in natural and agricultural ecosystems. In addition, the progressively expanding world population requires more land for agriculture and higher crop productivity. The big challenge here is to maintain the balance between the urge to increase crop yield using nanofertilizers while keeping their negative impact at minimum (Hong et al., 2013 and Khot et al., 2012). High variability of responses towards NPs application was observed among different plant species (Begum et al., 2012) and varieties (Tiwari et al., 2014) that depended primarily on the developmental stage of the plant at the time of application (Stampoulis et al., 2009). In general, it is known that nanoparticles can enhance plant growth at low concentrations but have adverse effect at relatively higher concentrations (Qian et al., 2013).

It had been reported that around $40 \%$ of the nanomaterials used in agriculture will be derived from carbon based nanomaterials (Gogos et al., 2012). These carbon allotropes or so called the wonder materials are comprised of carbon nanotubes (CNTs), fullerenes and graphene (Peng et al., 2014). The carbon allotropes exhibit outstanding new features that allow their use in wide applications worldwide (Zaytseva, 2016). Carbon nanotubes (CNT) are carbon cylinders

Corresponding author email: nohakhalifa@hotmail.com Mobile phone: 01009123211

DOI: 10.21608/ejbo.2018.3950.1181

C2018 National Information and Documentation Center (NIDOC) 
composed of benzene rings and mainly used as drug delivery systems for transporting and translocating therapeutic molecules in medicine (Bianco et al., 2005). However, there is high risk of nanocarbon tube toxicity at the cellular level (Kah \& Hofmann, 2015). CNT exhibits potential toxicities commonly by free radical formation (Muthu et al., 2013). There are two types of carbon nanotubes: Single walled carbon nanotube (SWCNT) and multiwalled carbon nanotube (MWCNT). SWCNT is more toxic than MWCNT (Cañas et al., 2008). SWCNTs are characterized by their electric conductivity while MWCNTs exhibit outstanding mechanical properties (Zaytseva, 2016). Many reports indicated that the ability of MWCNT to enhance plant growth and development is higher than that of SWCNT (Zaytseva \& Neumann, 2016). Despite the fact that both SWCNT and MWCNT were shown to exert adverse effect on the treated plants (Madani et al., 2013), MWCNT was used in this study since the potential of using it in agriculture is much higher.

The actual mechanism by which nanocarbon tubes exert their effect on plants is still equivocal. In addition, a standard approach to rapidly characterize the taxological behavior of NPs is still lacking (Kah \& Hofmann, 2015). Therefore, the main objective of this study is to determine the effect of MWCNT on pennycress (Thlaspi arvense L.) plants during early developmental stages based on root elongation assay and other plant pigment biosynthesis after treatment. The effect of MWCNT was directly investigated by its direct application on double stranded genomic DNA (dsg DNA) of the untreated plants.

In the present study, pennycress has been selected because the plant is related to the model plant species Arabidopsis thaliana. Many studies have been recently carried out on the genetics of pennycress in order to improve its potential use as a biofuel crop; the oil-rich seed can be harvested and used as a biodiesel feedstock (Dorn et al., 2013). Thus, pennycress is a good fit for a chain of research in order to investigate the mode of action of MWCNT and others at the molecular level. This will help to gain the ability to control the adverse reaction of NPs if applied to plants in the future.

\section{Materials and Methods}

\section{Plant materials}

Seeds of pennycress plants were a gift from
Sedbrook lab of plant molecular genetics, Biological Sciences Division, Illinois State University, Normal, IL., USA. Seeds were sterilized by $15 \%$ bleach for $15 \mathrm{~min}$ and then washed four times using sterile distilled water. Seeds were placed onto Petridishes supplied with wet filter paper and kept in dark (covered) inside a plant growth chamber at $21^{\circ} \mathrm{C}$ until germination. Homogeneously germinated seedlings were sterilized again and planted onto $1 \%$ MS agar media supplemented with different concentrations of MWCNT. Different concentrations of MWCNTS $(0,100,200 \mu \mathrm{g} /$ $\mu 1)$ were autoclaved at $121^{\circ} \mathrm{C}$ for $45 \mathrm{~min}$ as this material is stable at high temperature. The seeds were kept under long day condition (16h light $/ 8 \mathrm{~h}$ dark) for 6 days at $21^{\circ} \mathrm{C}$. The root lengths measurements were recorded every $24 \mathrm{~h}$ during this time.

Multiwalled carbon nanotube synthesis and characterization

MWCNT were synthesized using graphite powder (Sigma Aldrich, Germany) following the method of Hasaneen et al. (2017). Briefly, concentrated nitric and sulfuric acids were added to graphite powder in a ratio of 1 : 2: $0.2(\mathrm{~V}: \mathrm{V}: \mathrm{W})$, stirred for $30 \mathrm{~min}$ at room temperature, cooled at $5^{\circ} \mathrm{C}$ before slowly adding one gram of potassium chlorate, stirred for $30 \mathrm{~min}$, heated at $70^{\circ} \mathrm{C}$ for one day then placed in the open air for 3 days. All undissolved graphite was washed in $1 \mathrm{~L}$ deionized water and stirred for $1 \mathrm{~h}$ and then filtered. The filtrate was dried in the speed vacuum concentrator (Thermofisher, MA, USA). The dry sample was used to prepare the stock solution. The morphology and dispersion of MWCNT were examined using scanning Electron Microscope (SEM, JEOL 1010, Germany; analyzed at Central lab, El-Mansoura University) at $80 \mathrm{kV}$. Stock solution was sonicated for $2 \mathrm{~min}$ to assure complete dispersion. One drop was mounted onto carbon-coated copper grid and left to dry at room temperature. Dimensions of MWCNT were measured from the retrieved digital images using image $\mathrm{J}$ software program (Abràmoff et al., 2004).

\section{Zeta Potential}

The zeta potential of MWCNTs was measured using zeta sizer (Malvern Instruments Ltd, EM, Mansoura University). The synthesis of the material, the characterization and zeta 
potential measurement was conducted in the central lab, Mansoura University, Egypt.

\section{Root elongation assay}

Changes in root lengths over time were checked on the Petriplate every day for 6 days. At the end, plates were photographed by digital camera. Digital images were calibrated and analyzed by measuring root lengths changes over time using image $\mathrm{J}$ software program (Abràmoff et al., 2004).

\section{Plant pigment}

Leaves tissue was collected from the treated plants after 6 days of treatment with 0,100 and $200 \mu \mathrm{g} / \mu 1 \mathrm{MWCNT}$ to determine its effect on chlorophylls a, b and carotenoid pigments. $0.2 \mathrm{~g}$ of the first fully expanded leaves from the top of seedling were ground with aqueous acetone $(80 \%$ $\mathrm{w} / \mathrm{v})$. The resulted homogenate was centrifuged using cooling centrifuge at 5000rpm for $3 \mathrm{~min}$. The absorbance of the resulted supernatant (the pigments extract) was measured against wave lengths of 470, 537, 646 and $663 \mathrm{~nm}$. The plant pigments were determined in the amount of milligram tissue per milliliter following the equations of Porra 2002 for pigments dissolved in acetone based on 3 measurements:

Chlorophyll a $(\mathrm{mg} / \mathrm{ml})=12.25($ ë663) - $2.55($ ë 646)

Chlorophyll b $(\mathrm{mg} / \mathrm{ml})=20.31(\ddot{e} 646)-4.91($ ë 663.)

Total Chl. $(\mathrm{mg} / \mathrm{ml})=17.76(\ddot{\mathrm{e}} 646)+7.34(\ddot{\mathrm{e}} 663)$

Carotenoids $(\mathrm{mg} / \mathrm{ml})=(1000 * \ddot{e} 470-3.27[\mathrm{Chl}$

$$
\text { a] - 104[Chl b])/227 }
$$

\section{DNA extraction and gel electrophoresis}

Total genomic DNA was extracted from 5 grams of 3 week old seedlings of treated and untreated control plants. The method of Wen \& Ott (1983) was followed. The concentration of DNA content was measured spectrophotometrically at 260nm using Quawell Q5000UV-Vis spectrophotometer (V2.1.4, USA). DNA integrity was confirmed on 1\% agarose gel. Samples were stored at $-20^{\circ} \mathrm{C}$ until use. The DNA concentration in all experiments was adjusted into $2 \mu \mathrm{g}$ for $\mathrm{g}$ dsDNA or $5 \mu \mathrm{g}$ for the bacterial plasmid. DNA samples (either gds plant or plasmid DNA) were incubated with $0,100,200 \mu \mathrm{g} / \mu \mathrm{l}$ of MWCNT at $37^{\circ} \mathrm{C}$ for either 15 or $45 \mathrm{~min}$ and then loaded onto $0.7 \%$ agarose then ran for $1 \mathrm{~h}$ at $70 \mathrm{~V}$ in the presence of DNA marker. The gel was stained with ethidium bromide and visualized using gel document system (Syngene, Cambridge, UK). The digital image was then analyzed for DNA binding assay or degradation assay using gel documentation software (Genetools, Syngene, Cambridge, UK).

\section{$\underline{\text { Results and Discussion }}$}

The hazards associated with engineered nanomaterials (ENM) could be determined by their interaction with living organisms during their accumulation within the environment. Environmental factors, the type of living tissue, the nature and the concentration of the ENM will determine the level of exposure and consequently the corresponding damage (Handy et al., 2008).

In this study, the MWCNT nanoparticles were characterized and their homogeneous distribution was confirmed using SEM (Fig. 1). On average, MWCNT length $=559.54 \mathrm{~nm} \pm 0.48$ and width= $56.50 \mathrm{~nm} \pm 0.67$ (Fig 1). Although the diameter and length of MWCNTs are frequently greater than the size of fullerenes and SWCNTs, their uptake and internal translocation by plants are still efficient (Lahiani et al., 2013). MWCNT can penetrate cells of developing seedlings, as well as rigid seed coats by perforation and making new pores (Khodakovskaya et al., 2009). MWCNTs with a diameter of $110-170 \mathrm{~nm}$ showed the ability to pierce the epidermal cell wall of wheat and penetrate up to $4 \mu \mathrm{m}$ into the cytosol (Wild \& Jones, 2009). Translocation of MWCNTs from roots to xylem and phloem is likely driven by the process of transpiration (Chen et al., 2015). MWCNT uptake in root cells of onion (Allium cepa) had significantly altered cellular morphology and resulted in comprising membrane integrity, induced DNA damage, chromosomal aberrations and DNA hypermethylation (Ghosh et al., 2015). It is also reported that MWCNT increases ROS formation (Begum \& Fugetsu, 2012 and Katti et al., 2015) and alteration in gene expression (Khodakovskaya et al., 2013). The CNT uptake by living cells is likely to occur via energy dependent endocytosis (Shi Kam et al., 2004). The zeta potential of MWCNT in this study indicates that its maximum stability occurs at the neutral $\mathrm{pH}=7$ as shown in Fig. 2. 


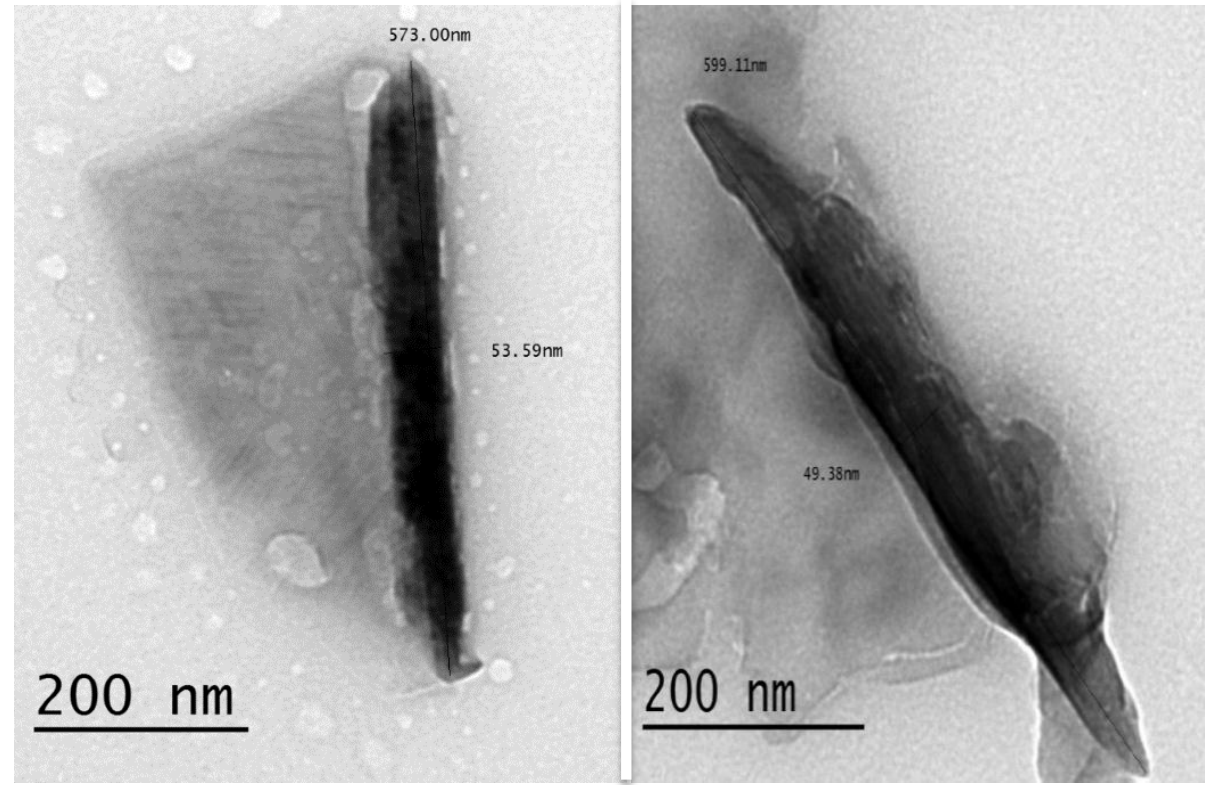

Fig. 1. SEM micrograph of multiwallednano carbon tube (Note the dimension of the closed end multiwalled carbon nanotube).

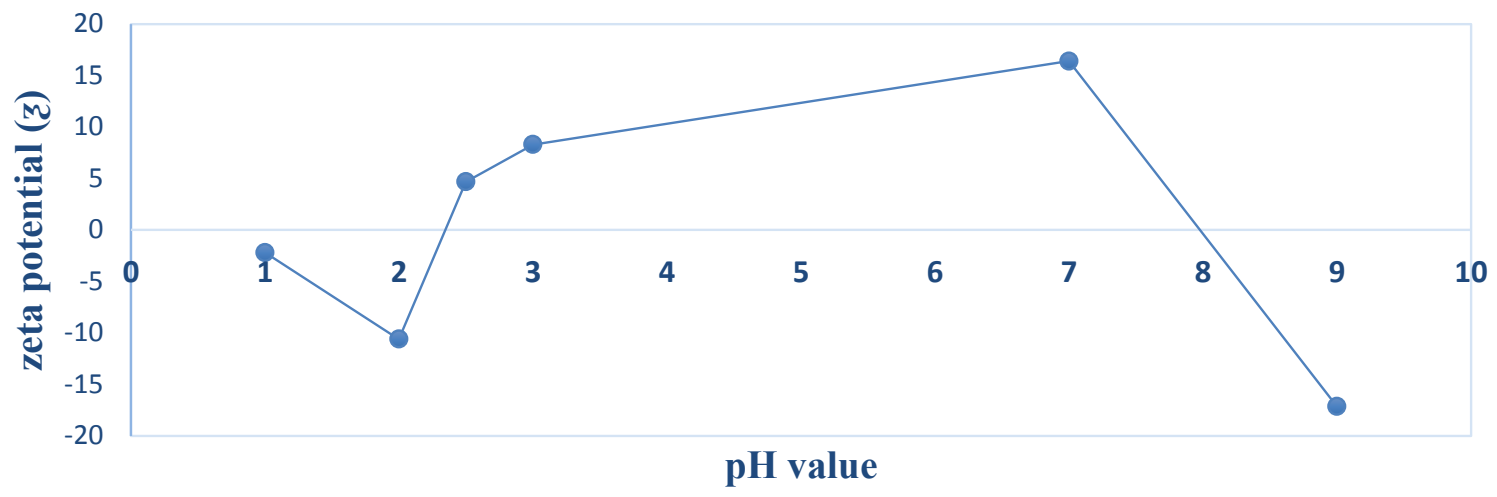

Fig. 2. Zeta potential of MWCNT against different values of pH. The figure indicates that the highest stability of the MWCNT used in this study was found at the neutral medium $(\mathrm{pH}=7)$.

Most of studies that focused on MWCNTs effects on plant growth and development have used hydroponics or agar growth media. Soil culture had been employed very rarely due to limited mobility of MWCNTs in soil (Kasel et al., 2013). For this reason, 1\% MS agar medium was used herein as a growth medium to determine the effect of $0,25,100$ and $200 \mu \mathrm{g} /$ $\mu 1$ MWCNT on pennycress plants for 6 days. During the treatment time, root elongation rate was daily recorded (Fig. 3 and 4). In the present case, there was no significant difference in root length in case of application of $25 \mu \mathrm{g} / \mu \mathrm{l}$ and the untreated control (Fig. 3 and 4). On the other hand, MWCNT at higher concentrations of 100 and $200 \mu \mathrm{g} / \mu \mathrm{l}$ reduced the root elongation rate (Fig. 3 and 4).
Despite of the ability of CNTs to enhance number and fruit bloom in tomato, yet there were some concerns about the toxological risks due to the accumulation of MWCNT within the fruit (McGehee et al., 2017). Ghosh et al. (2015) reported DNA damage, micronucleus formation and chromosome aberration in onion roots (Allium сера) in response to MWCNT treatments. In tomato roots (Solanum lycopersicum), MWCNTs triggered overexpression of various biotic stress-related genes such as those of aquaporin (Villagarcia et al., 2012). Thus, MWCNTs seed treatments may reflect a common stress response with the ability to induce plant defense genes or results in toxicities depending on the intensity of the stimulus (Lahiani et al., 2013). 


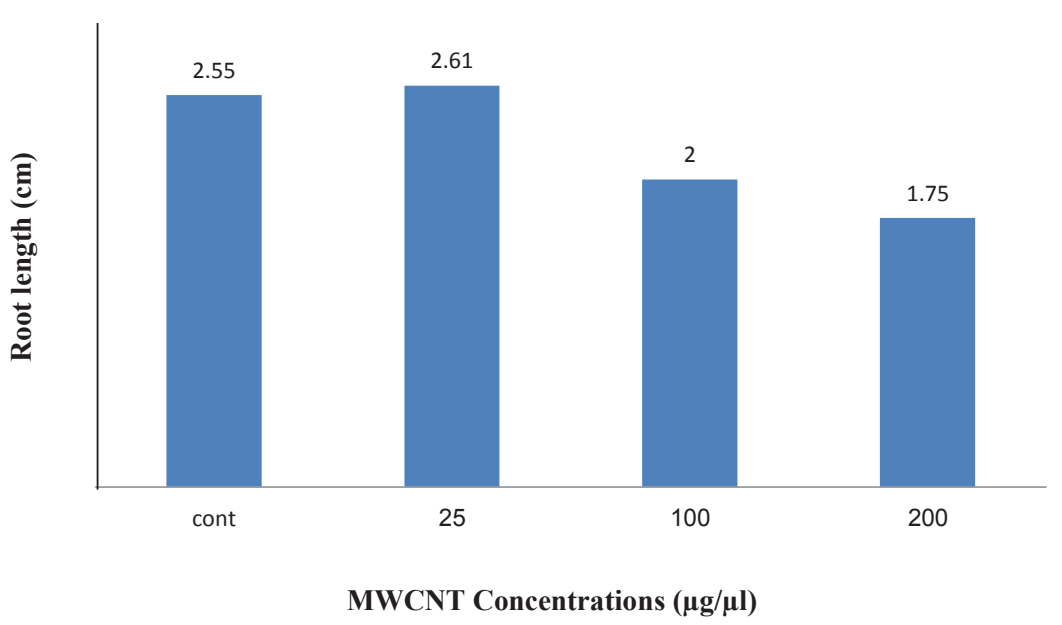

Fig. 3. Root elongation bioassay for pennycress seedlings grown on MS media supplemented with $0,25,100$ and $200 \mu \mathrm{g} / \mu \mathrm{l}$ of MWCNT for 6 days.

Giraldo et al. (2014) exploited the interaction between plant organelles such as chloroplast and SWNCT to enhance photosynthesis by unknown mechanism (Giraldo et al., 2014). On contrary, the data of this study indicated that MWCNT caused a decreased chlorophylls a, b and consequently total chlorophyll in a dose dependent manner (Table 1). The result of the current research is concomitant with that of Lin et al. (2009) where MWCNT reduced chlorophyll pigment in Arabidopsis plants. Interestingly, carotenoid pigments increased to 525 . $69 \mathrm{mg} / \mathrm{ml}$ at $100 \mu \mathrm{g} / \mu \mathrm{l}$ MWCNT then decreased to $2.8 \mathrm{mg} / \mathrm{ml}$ after 6 days of treatment, compared with carotenoid content in corresponding control plants $(18.13 \mathrm{mg} / \mathrm{ml})$ (Table 1). It is known that carotenoids are stress sensors/ signals in plants (Shumbe et al., 2014). Thus, carotenoids are likely overexpressed to protect plant tissues from the oxidative stress of MWCNT at relatively moderate high concentrations, i.e. 100 but not $200 \mu \mathrm{g} / \mu \mathrm{l}$.

Recent studies showed that CNT toxicity, in many cases, is not associated with free radical formation but rather induced DNA damage in living cells (Tsukahara \& Haniu, 2011). The uptake of CNT is suggested to influence plants potentially through its interaction with DNA (Zaytseva, 2016). $\mathrm{CNT}$ is also able to bind metals in biological systems and induce ROS production (Yadav \& Kumar, 2008). Molecular dynamics simulations showed that the DNA can wrap onto SWCNT and consequently modify its conformation (Katti et al., 2015). Agarose gel electrophoresis can be used to determine the binding ability of the nanoparticle to DNA (Uritu et al., 2013). In the present study, free untreated DNA was incubated at $37^{\circ} \mathrm{C}$ with
0, 25100 and $200 \mu \mathrm{g} / \mu \mathrm{l}$ of MWCNT for either 15 or $45 \mathrm{~min}$. The same result was recorded with both incubation times indicating that it is not a limited factor as shown in Fig. 5. Yet, incubation at $37^{\circ} \mathrm{C}$ is necessary for the interaction to take place. I noticed a mobility shift in DNA incubated with higher concentrations of $100 \& 200 \mu \mathrm{g} / \mu \mathrm{l}$ of MWCNT (Fig. 5). On the other hand, DNA incubated with $25 \mu \mathrm{g} / \mu \mathrm{l}$ of MWCNT was comparable to the control (Fig. 5). This was assumed due to binding of MWCNT with DNA at high concentrations. Other studies documented fullerene conjugates where buckyball C60 carbon acted as an efficient binder to double stranded DNA (dsDNA) (Uritu et al., 2013). This binding reaction can happen with genomic DNA either in its free form (in vitro) or within intact cells (In vivo) and do have many medical applications (Partha \& Conyers, 2009). Buckminster fullerene $\mathrm{C} 60$ is a member in carbon allotrope family and contains 60 carbon atoms with $\mathrm{C}_{5}-\mathrm{C}_{5}$ single bonds forming pentagons and $\mathrm{C}_{5}-$ $\mathrm{C}_{6}$ double bonds forming hexagons (Kroto et al., 1985). However, and to the best of my knowledge, I could not retrieve any information in relation to DNA binding to MWCNT.

\section{Conclusion}

DNA gel binding assay could be used to determine the nature of interaction between NPs and DNA. This will help also to identify the optimum dose of treatment in the crop field. Thus, it might be concluded that there are still many concerns with respect to the biosafety of applying MWCNT to the living cells. 
TABLE 1. Effect of MWCNT on plant pigment content of pennycress plants treated with different concentrations.

\begin{tabular}{lcccc}
\hline Pigment in $\boldsymbol{\mu g} / \mathbf{m l}$ & Cont & 25 CNT & 100 CNT & 200 CNT \\
\hline Chl. a $(\mu \mathrm{g} / \mathrm{ml})$ & 0.94 & 0.21 & 0.1 & 0.05 \\
Chl. b & 0.82 & 0.36 & 0.16 & 0.05 \\
Total Chl. & 1.27 & 0.39 & 0.18 & 0.07 \\
Anthocyanin & 0.003 & 0.0007 & 0.00033 & 0.0002 \\
Carotenoids & 18.13 & 39.46 & 525.69 & 2.8 \\
\hline
\end{tabular}

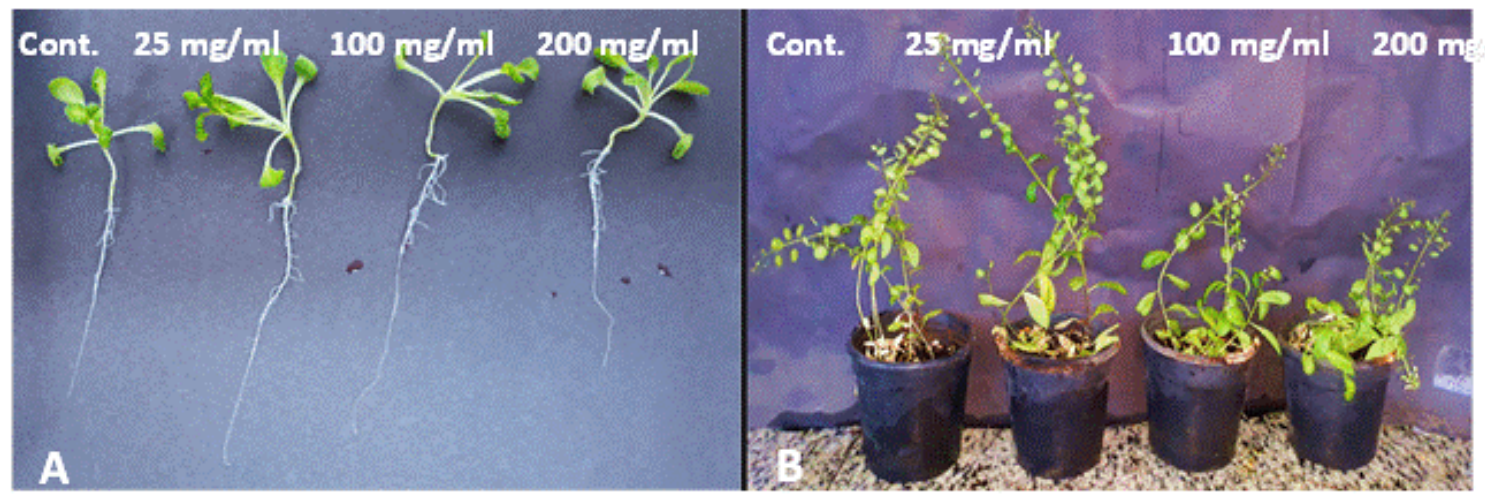

Fig. 4. Effect of MWCNT o pennycress plants. The effect was observed in 2 weeks old plants (A) and 2 months old plant (B) after treatment with different concentrations of MWCNT while grwoing on MS media for one week.

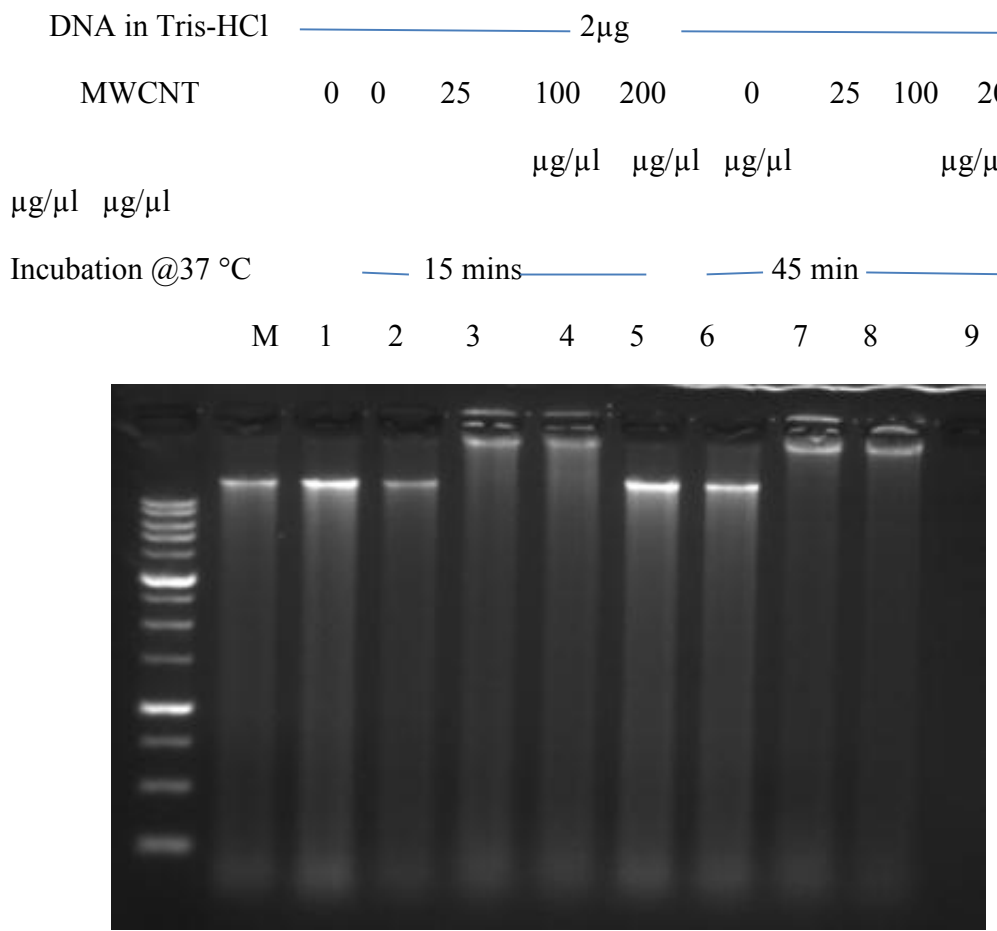

Fig. 5. Incubation of double strand genomic DNA (ds g DNA) with 25,100 or $200 \mu \mathrm{g} / \mu \mathrm{l}$ of $\mathrm{MWCNT}$ at $37^{\circ} \mathrm{C}$ for $15 \mathrm{~min}$ (samples from 2-5) or 45min (samples from 6-9). Control is dsgDNA only at room temperature (sample 1) or incubated at $37^{\circ} \mathrm{C}$ for $15 \mathrm{~min}$ (2) or $45 \mathrm{~min}(6)$ (Note that at $25 \mu \mathrm{g} / \mu \mathrm{l}$ of MWCNT, no shift in the molecular weight occurred either after incubations for $15 \mathrm{~min}$ (3) or $45 \mathrm{~min}$ (7). On the other hand, at higher concentrations of 100 and 200 , there was a shift in the molecular weight either $15 \min (4,5)$ or $45 \mathrm{~min}(8,9)$ incubation at $\left.37^{\circ} \mathrm{C}\right)$. 


\section{References}

Abràmoff, M.D., Magalhães, P.J. and Ram, S.J. (2004) Image processing with image. J. Biophotonics International. https://doi.org/10.1117/1.3589100

Begum, P. and Fugetsu, B. (2012) Phytotoxicity of multi-walled carbon nanotubes on red spinach (Amaranthus tricolor $\mathrm{L}$ ) and the role of ascorbic acid as an antioxidant. Journal of Hazardous Materials, 243, 212-222. https://doi.org/10.1016/j. jhazmat.2012.10.025

Begum, P., Ikhtiari, R., Fugetsu, B., Matsuoka, M., Akasaka, T. and Watari, F. (2012) Phytotoxicity of multi-walled carbon nanotubes assessed by selected plant species in the seedling stage. Applied Surface Science, 262(262), 120-124. https://doi. org/10.1016/j.apsusc.2012.03.028

Bianco, A., Kostarelos, K. and Prato, M. (2005) Applications of carbon nanotubes in drug delivery. Current Opinion in Chemical Biology, 9(6), 674679. https://doi.org/10.1016/j.cbpa.2005.10.005

Cañas, J.E., Long, M., Nations, S., Vadan, R., Dai, L., Luo, M., Ambikapathi, R., Lee, E.H. and Olszyk, D. (2008) Effects of functionalized and nonfunctionalized single-walled carbon nanotubes on root elongation of select crop species. Environmental Toxicology and Chemistry, 27(9), 1922-1931. Retrieved from http://www.ncbi.nlm. nih.gov/pubmed/19086209

Chen, G., Qiu, J., Liu, Y., Jiang, R., Cai, S., Liu, Y., Zhu, F., Zeng, F., Luan, T. and Ouyang, G. (2015) Carbon nanotubes act as contaminant carriers and translocate within plants. Scientific Reports, 5(1), 15682. https://doi.org/10.1038/srep15682

De Jong, W.H. and Borm, P.J.A. (2008) Drug delivery and nanoparticles: Applications and hazards. International Journal of Nanomedicine, 3(2), 133149. Retrieved from http://www.ncbi.nlm.nih.gov/ pubmed/18686775

Dorn, K.M., Fankhauser, J.D., Wyse, D.L. and Marks, M.D. (2013) De novo assembly of the pennycress (Thlaspi arvense) transcriptome provides tools for the development of a winter cover crop and biodiesel feedstock. The Plant Journal, 75(6), 1028-1038. https://doi.org/10.1111/tpj.12267

Ghosh, M., Bhadra, S., Adegoke, A., Bandyopadhyay,
M. and Mukherjee, A. (2015) MWCNT uptake in Allium cepa root cells induces cytotoxic and genotoxic responses and results in DNA hypermethylation. Mutation Research/Fundamental and Molecular Mechanisms of Mutagenesis, 774, 4958. https://doi.org/10.1016/j.mrfmmm.2015.03.004

Giraldo, J.P., Landry, M.P., Faltermeier, S.M., McNicholas, T.P., Iverson, N.M., Boghossian, A.A., Reuel, N.F., Hilmer, A.J., Sen, F., Brew, J.A. and Strano, M.S. (2014) Plant nanobionics approach to augment photosynthesis and biochemical sensing. Nature Materials, 13(4), 400-408. https:// doi.org/10.1038/nmat3890

Gogos, A., Knauer, K. and Bucheli, T.D. (2012) Nanomaterials in plant protection and fertilization: current state, foreseen applications, and research priorities. Journal of Agricultural and Food Chemistry, 60(39), 9781-9792. https://doi. org/10.1021/jf302154y

Handy, R.D., von der Kammer, F., Lead, J.R., Hassellöv, M., Owen, R. and Crane, M. (2008) The ecotoxicology and chemistry of manufactured nanoparticles. Ecotoxicology, 17(4), 287-314. https://doi.org/10.1007/s10646-008-0199-8

Hasaneen, N., Abdel-Aziz, H. and Omer, A. (2017) Characterization of carbon nanotubes loaded with nitrogen, phosphorus and potassium fertilizers. American Journal of Nano Research and Applications, 5(2), 12-18. https://doi. org/10.11648/j.nano.20170502.11

Hong, J., Peralta-Videa, J.R. and Gardea-Torresdey, J.L. (2013) "Nanomaterials in Agricultural Production: Benefits and Possible Threats", pp. 73-90. https:// doi.org/10.1021/bk-2013-1124.ch005

Kah, M. and Hofmann, T. (2015) The Challenge: Carbon nanomaterials in the environment: New threats or wonder materials. Environmental Toxicology and Chemistry, 34(5), 954-954. https:// doi.org/10.1002/etc. 2898

Kasel, D., Bradford, S.A., Rí, J., Unek, S., Pütz, T., Vereecken, H. and Klumpp, E. (2013) Limited transport of functionalized multi-walled carbon nanotubes in two natural soils. Environmental Pollution, 180, 152-158. https://doi.org/10.1016/j. envpol.2013.05.031

Katti, D.R., Sharma, A., Pradhan, S.M. and Katti, K.S. 
(2015) Carbon nanotube proximity influences rice DNA. Chemical Physics, 455, 17-22. https://doi. org/10.1016/j.chemphys.2015.03.015

Khodakovskaya, M., Dervishi, E., Mahmood, M., Xu, Y., Li, Z., Watanabe, F. and Biris, A.S. (2009) Carbon nanotubes are able to penetrate plant seed coat and dramatically affect seed germination and plant growth. ACS Nano, 3(10), 3221-3227. https:// doi.org/10.1021/nn900887m

Khodakovskaya, M., Kim, B.S., Kim, J.N., Alimohammadi, M., Dervishi, E., Mustafa, T. and Cernigla, C.E. (2013) Carbon nanotubes as plant growth regulators: Effects on tomato growth, reproductive system, and soil microbial community Small, 9(1), 115-123. https://doi.org/10.1002/ smll.201201225

Khot, L.R., Sankaran, S., Maja, J.M., Ehsani, R. and Schuster, E.W. (2012) Applications of nanomaterials in agricultural production and crop protection: A review. Crop Protection, 35, 64-70. https://doi.org/10.1016/J.CROPRO.2012.01.007

Kovtun, A., Neumann, S., Neumeier, M., Urch, H., Heumann, R., Gepp, M.M., Wallat, K., Koeller, M., Zimmermann, H. and Epple, M. (2013) Nanoparticlemediated gene transfer from electrophoretically coated metal surfaces. The Journal of Physical Chemistry $B$ 117(6), 1550-1555. https://doi.org/10.1021/ jp303448v

Kroto, H.W., Heath, J.R., O'Brien, S.C., Curl, R.F. and Smalley, R.E. (1985) C60: Buckminsterfullerene. Nature, 318(6042), 162-163. https://doi. org/10.1038/318162a0

Lahiani, M.H., Dervishi, E., Chen, J., Nima, Z., Gaume, A., Biris, A.S. and Khodakovskaya, M.V. (2013) Impact of carbon nanotube exposure to seeds of valuable crops ACS. Applied Materials \& Interfaces, 5(16), 7965-7973. https://doi. org/10.1021/am402052x

Lin, C., Fugetsu, B., Su, Y. and Watari, F. (2009) Studies on toxicity of multi-walled carbon nanotubes on Arabidopsis T87 suspension cells. Journal of Hazardous Materials, 170(2-3), 578583. https://doi.org/10.1016/j.jhazmat.2009.05.025

Madani, S.Y., Mandel, A. and Seifalian, A.M. (2013) A concise review of carbon nanotube's toxicology. Nano Reviews, 4. https://doi.org/10.3402/nano.v4i0.21521.
McGehee, D.L., Lahiani, M.H., Irin, F., Green, M.J. and Khodakovskaya, M.V. (2017) Multiwalled carbon nanotubes dramatically affect the fruit metabolome of exposed tomato plants. ACS Applied Materials \& Interfaces, 9(38), 32430-32435. https://doi. org/10.1021/acsami.7b10511

Mehrazar, E., Rahaie, M. and Rahaie, S. (2015) Application of nanoparticles for pesticides, herbicides, fertilisers and animals feed management. International Journal of Nanoparticles, 8(1), 1. https://doi.org/10.1504/IJNP.2015.070339

Muthu, M.S., Abdulla, A. and Pandey, B.L. (2013) Major toxicities of carbon nanotubes induced by reactive oxygen species: Should we worry about the effects on the lungs, liver and normal cells? Nanomedicine, 8(6), 863-866. https://doi. org/10.2217/nnm.13.60

Partha, R. and Conyers, J.L. (2009) Biomedical applications of functionalized fullerenebased nanomaterials. International Journal of Nanomedicine, 4, 261-275. Retrieved from http:// www.ncbi.nlm.nih.gov/pubmed/20011243

Peng, Q., Crean, J., Han, L., Liu, S., Wen, X., De, S. and Dearden, A. (2014) New materials graphyne, graphdiyne, graphone, and graphane: Review of properties, synthesis and application in nanotechnology. Nanotechnology, Science and Applications, 7, 1. https://doi.org/10.2147/NSA. S40324

Qian, H., Peng, X., Han, X., Ren, J., Sun, L. and Fu, Z. (2013) Comparison of the toxicity of silver nanoparticles and silver ions on the growth of terrestrial plant model Arabidopsis thaliana. Journal of Environmental Sciences, 25(9), 1947-1956. https://doi.org/10.1016/S10010742(12)60301-5

Shi Kam, N.W., Jessop, T.C., Wender, P.A. and Dai, H. (2004) Nanotube molecular transporters: Internalization of carbon nanotube-protein conjugates into mammalian cells. Journal of the American Chemical Society, 126(22), 6850-6851. https://doi.org/10.1021/ja0486059

Shumbe, L., Bott, R. and Havaux, M. (2014) Dihydroactinidiolide, a high light-induced $\beta$-carotene derivative that can regulate gene expression and photoacclimation in Arabidopsis. Molecular Plant, 7(7), 1248-1251. https://doi. 
$\operatorname{org} / 10.1093 / \mathrm{mp} / \mathrm{ssu} 028$

Siddiqi, K.S. and Husen, A. (2016) Engineered gold nanoparticles and plant adaptation potential. Nanoscale Research Letters, 11(1), 400. https://doi. org/10.1186/s11671-016-1607-2

Stampoulis, D., Sinha, S.K. and White, J.C. (2009) Assay-dependent phytotoxicity of nanoparticles to plants. Environmental Science \& Technology, 43(24), 9473-9479. https://doi.org/10.1021/ es $901695 \mathrm{c}$

Tiwari, D.K., Dasgupta-Schubert, N., Villaseñor Cendejas, L.M., Villegas, J., Carreto Montoya, L. and Borjas García, S.E. (2014) Interfacing carbon nanotubes (CNT) with plants: Enhancement of growth, water and ionic nutrient uptake in maize (Zea mays) and implications for nanoagriculture. Applied Nanoscience, 4(5), 577-591. https://doi. org/10.1007/s13204-013-0236-7

Tsukahara, T. and Haniu, H. (2011) Cellular cytotoxic response induced by highly purified multi-wall carbon nanotube in human lung cells. Molecular and Cellular Biochemistry, 352(1-2), 57-63. https://doi.org/10.1007/s11010-011-0739-z

Uritu, C.M., Varganici, C.D., Ursu, L., Coroaba, A., Nicolescu, A., Dascalu, A.I., Peptanariu, D., Stan, D., Constantinescu, C.A., Simion, V., Calin, M., Maier, S.S., Pinteala, M. and Barboiu, M. (2013) Hybrid fullerene conjugates as vectors for DNA cell-delivery. J. Mater. Chem. B, 3, 2433-2446. https://doi.org/10.1039/x0xx00000x

Villagarcia, H., Dervishi, E., de Silva, K., Biris, A.S. and Khodakovskaya, M.V. (2012) Surface chemistry of carbon nanotubes impacts the growth and expression of water channel protein in tomato plants. Small, 8(15), 2328-2334. https://doi. $\operatorname{org} / 10.1002 / \mathrm{smll} .201102661$

Wen, T.J. and Ott, A. (1983) Dellaporta DNA extraction. Plant Molecular Biology Reporter, 1(4), 19-21. Retrieved from https://schnablelab.plantgenomics. iastate.edu/docs/resources/protocols/pdf/ Dellaporta_DNA_Extraction.2014.08.20.pdf

Wild, E. and Jones, K.C. (2009) Novel method for the direct visualization of in vivo nanomaterials and chemical interactions in plants. Environmental Science \& Technology, 43(14), 5290-5294. https:// doi.org/10.1021/es900065h

Yadav, B.C. and Kumar, R. (2008) Structure, properties and applications of fullerenes. International Journal of Nanotechnology and Applications, 973(1), 1524. Retrieved from http://www.ripublication.com/ ijna.htm

Zaytseva, O. (2016) Analysis of phytotoxicity and plant growth stimulation by multi-walled carbon nanotubes. Stuttgart-Hohenheim. Retrieved from http://opus.uni-hohenheim.de/volltexte/2017/1417/ pdf/Thesis_Zaytseva.pdf

Zaytseva, O. and Neumann, G. (2016) Carbon nanomaterials: Production, impact on plant development, agricultural and environmental applications. Chemical and Biological Technologies in Agriculture, 3(1), 17. https://doi.org/10.1186/ s40538-016-0070-8

(Received 26/ 5/2018; accepted 19/6/2018)
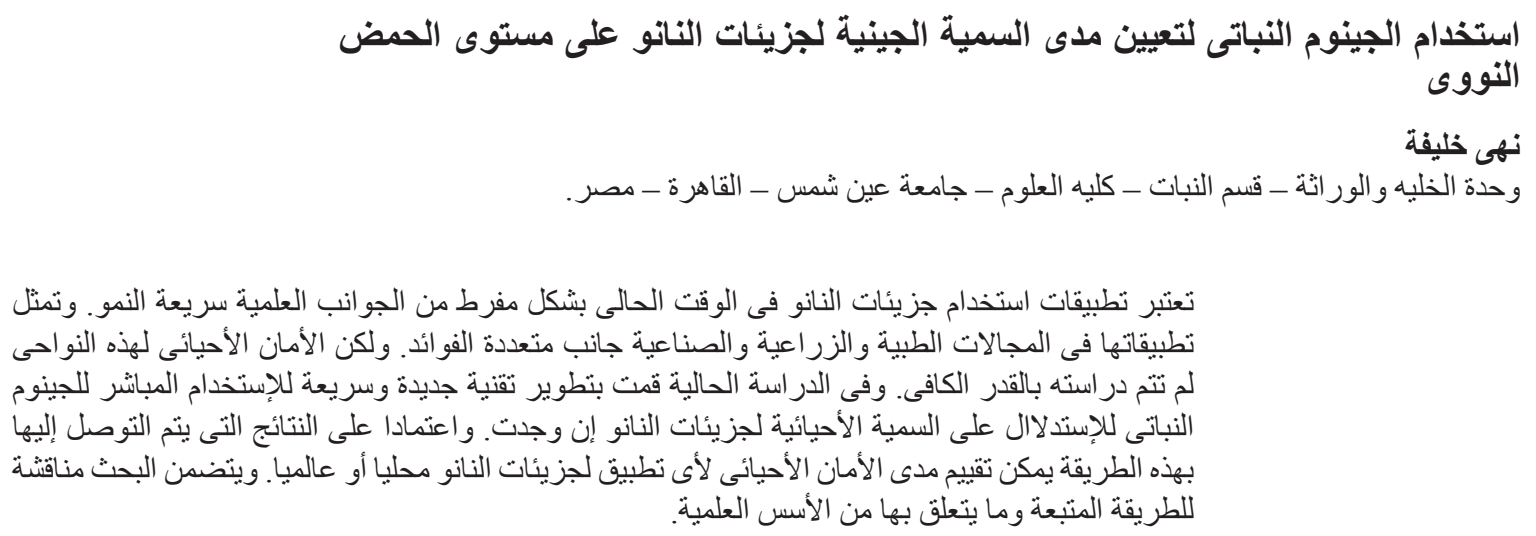